\title{
MENENTUKAN KOMPOSISI OPTIMAL DARI FAKTOR- FAKTOR YANG MEMENGARUHI KETAHANAN ASPAL DENGAN METODE TAGUCHI
}

\author{
Gusti Ayu Putu Yuliandari ${ }^{1}$, I GuSti Ayu Made Srinadi ${ }^{2}$, \\ I WAYAN SUMARJAYA ${ }^{3}$ \\ 1, 2,3 Jurusan Matematika FMIPA Universitas Udayana, Bukit Jimbaran-Bali, \\ e-mail: ${ }^{1}$ yoelygirlz@yahoo.com \\ ${ }^{2}$ srinadiigustiayumade@yahoo.co.id, ${ }^{3}$ sumarjaya@gmail.com
}

\begin{abstract}
Taguchi method purpose to improve the quality of a product. This method can reduce the number of execution of the experiment when compared to using a full factorial method. measures taken, namely the calculation of degrees of freedom, the selection of orthogonal array to reduce the run, then calculating $S / N R$ is used to determine the optimal composition of the factors that will affect the durability of asphalt. The results of this research that the optimal composition of the factors that affect the resistance of asphalt are aggregate of 6987.57 tons, temperature of $155^{\circ}$ $C$, compaction speed $5 \mathrm{~km} / \mathrm{h}$, hardening time for 4 hours after paving before the opening of traffic at normal speed, thickness of $6.27 \mathrm{~cm}$ thick bitumen from the aggregate surface, body weight that is weighing 7 ton. Dimensions of factors is an area of $5.598 \mathrm{~m}$.
\end{abstract}

Keywords: Taguchi Methods, Degrees of Freedom, Signal to Noise Ratio (S/NR), Orthogonal Array.

\section{Pendahuluan}

Jalan merupakan salah satu prasarana transportasi darat sebagai penghubung antara satu daerah dengan daerah lainnya. Pertumbuhan populasi penduduk yang semakin cepat dan meningkatnya mobilitas penduduk berdampak kepada meningkatnya penggunaan jalan. Peningkatan terhadap penggunaan jalan tersebut berdampak terhadap kerusakan jalan. Kualitas jalan secara fisik dapat dilihat dari mutu aspal yang digunakan sebagai lapisan pengikat dan merupakan lapisan paling atas dari suatu jalan. Aspal didefinisikan sebagai material berwarna hitam atau coklat tua, pada temperatur ruang berbentuk padat sampai agak padat. Jika dipanaskan dalam temperatur tertentu aspal akan menjadi lunak atau cair sehingga dapat membungkus partikel agregat pada waktu pembuatan aspal atau dapat masuk dalam pori-pori yang ada pada penyemprotan atau penyiraman pada perkerasan macadam ataupun pelaburan (Sukirman,[4]). Sehingga ketahanan aspal menjadi faktor penting dalam menentukan baik atau tidaknya mutu suatu jalan.

\footnotetext{
${ }^{1}$ Alumni Mahasiswa Jurusan Matematika FMIPA Universitas Udayana

${ }^{2,3}$ Staf Pengajar Jurusan Matematika FMIPA Universitas Udayana
} 
Metode Taguchi merupakan salah satu metode yang digunakan untuk meningkatkan mutu suatu produk. Metode ini dapat mengurangi jumlah pelaksanaan percobaan jika dibandingkan dengan menggunakan metode faktorial penuh (full factorial) (Esme,[5]). Selain itu metode ini, dapat menghemat waktu dan biaya, dan dapat mengetahui faktor-faktor yang berpengaruh terhadap karakteristik mutu melalui perhitungan Signal to Noise Ratio (Rasio S/N), sehingga faktor-faktor yang berpengaruh tersebut dapat diberikan perhatian khusus.

\section{Metode Penelitian}

Data yang digunakan dalam penelitian ini merupakan data sekunder. Data berasal dari laboratorium Satuan Kerja Pelaksanaan Jalan Nasional Metropolitan Denpasar tahun 2012 [3], berupa data mutu peningkatan jalan Cokroaminoto sampai Tohpati (Jalan Gatsu Timur) sepanjang 5,36 km.

Pengolahan data pada penelitian ini menggunakan bantuan program Minitabl4 For Windows. Dengan langkah-langkah yaitu penentuan variabel tak bebas, identifikasi variabel bebas, penentuan faktor kontrol dan faktor gangguan, penentuan banyak level dan nilai level faktor, perhitungan derajat kebebasan (Degrees of Freedom), pemilihan orthogonal array Taguchi untuk mengurangi run sehingga menghemat waktu dan biaya percobaan, lalu dilakukan perhitungan S/NR yang digunakan untuk mengetahui komposisi optimal faktor-faktor yang akan memengaruhi ketahanan aspal.

\section{Hasil dan Pembahasan}

Variabel takbebas dalam penelitian ini adalah ketahanan aspal (Y) yang termasuk karakteristik Smaller the better karena semakin kecil kemungkinan lemahnya ketahanan aspal maka akan lebih baik, atau semakin kuat ketahanan suatu aspal maka akan semakin baik. Variabel bebasnya yaitu agregat $\left(X_{1}\right)$, temperatur $\left(X_{2}\right)$, kecepatan pemadatan $\left(X_{3}\right)$, waktu pengerasan $\left(X_{4}\right)$, ketebalan aspal $\left(X_{5}\right)$, berat beban benda pengeras $\left(X_{6}\right)$, dan dimensi (luas) $\left(X_{7}\right)$, dengan ketentuan katagori sebagai berikut:

Table 1. Kategori Dari Faktor-Faktor Ketahanan Aspal

\begin{tabular}{|l|c|c|c|}
\hline \multicolumn{1}{|c|}{ Faktor } & \multicolumn{3}{c|}{ Level } \\
\hline Agregat & Halus & Kasar & Sangat kasar \\
\hline Temperatur & Rendah & Sedang & Tinggi \\
\hline Kecepatan pemadatan & Lambat & Cepat & Sangat cepat \\
\hline Waktu pengerasan & Sangat lambat & Lambat & Cepat \\
\hline Ketebalan Aspal & Tipis & Tebal & Sangat tebal \\
\hline Berat beban benda pengeras & Ringan & Sedang & Berat \\
\hline Dimensi (Luas) & Kurang lebar & Lebar & Sangat lebar \\
\hline
\end{tabular}


Setelah menentukan banyak dari level-level data maka akan dilakukan untuk penentuan komposisi nilai-nilai dari level-level faktor pada penelitian ini yang sangat memengaruhi ketahanan aspal. Adapun nilai-nilai dari level-level faktor dalam penelitian ini yaitu:

Table 2. Nilai dari Level Faktor Ketahanan Aspal

\begin{tabular}{|l|c|c|c|c|}
\hline \multirow{2}{*}{ Faktor } & \multirow{2}{*}{ Satuan } & \multicolumn{3}{c|}{ Level } \\
\cline { 3 - 5 } & & $\mathbf{1}$ & $\mathbf{2}$ & $\mathbf{3}$ \\
\hline Agregat & ton & $6.987,57$ & $10.481,36$ & $11.696,58$ \\
\hline Temperatur & ${ }^{\circ} \mathrm{C}$ & 155 & 165 & 175 \\
\hline Kecepatan pemadatan & $\mathrm{km} / \mathrm{jam}$ & 5 & 6 & 7 \\
\hline Waktu pengerasan & $\mathrm{jam}$ & 2 & 3 & 4 \\
\hline Ketebalan Aspal & $\mathrm{cm}$ & 6,27 & 7,02 & 7.36 \\
\hline $\begin{array}{l}\text { Berat beban benda } \\
\text { pengeras }\end{array}$ & ton & 6 & 7 & 8 \\
\hline Dimensi (Luas) & $\mathrm{cm}$ & 4,598 & 5,751 & 6,765 \\
\hline
\end{tabular}

Kemudian dilakukan perhitungan derajat kebebasan (db) untuk menentukan jumlah minimum percobaan yang harus dilakukan untuk menyelidiki faktor yang diamati (Bagchi,[1]).

Rumus umum Jumlah total:

$$
D b=\text { jumlah faktor } \times(\text { jumlah level }-1)
$$

Perhitungan derajat kebebasan (db) 3 level 7 faktor yaitu sebagai berikut:

$$
\begin{aligned}
d b & =\text { Banyak faktor } \times(\text { banyak level }-1) \\
& =7 \times(3-1) \\
& =7 \times 2 \\
& =14
\end{aligned}
$$

Dengan demikian paling sedikit run yang harus dilakukan pada penelitian 3 level 7 faktor adalah 14 kali.

Kemudian akan dilakukan pemilihan Orthogonal Array (OA) yang telah menyediakan berbagai matriks untuk pengujian faktor-faktor dengan dua dan tiga level dengan kemungkinan pengembangan untuk pengujian level berganda (multiple level) (Ross,[2]). Pemilihan Orthogonal Array (OA) harus diperhatikan banyak faktor yang diamati. Dalam penelitian ini semua faktor terdiri dari 3 level maka dipilih jenis OA untuk 3 level faktor yaitu $L_{27}$ karena jumlah run pada OA harus lebih besar atau sama dengan derajat bebas (db) (Ross,[2]). 
Table 3. Tampilan Jumlah Run pada Percobaan 3 Level 7 Faktor

\begin{tabular}{|c|c|c|c|c|c|c|c|c|}
\hline \multirow{2}{*}{ Run } & \multicolumn{7}{|c|}{ Faktor } & \multirow{2}{*}{$\mathrm{Y}$} \\
\cline { 2 - 8 } & $\mathrm{A}$ & $\mathrm{B}$ & $\mathrm{C}$ & $\mathrm{D}$ & $\mathrm{E}$ & $\mathrm{F}$ & $\mathrm{G}$ & \\
\hline 1 & 1 & 1 & 1 & 1 & 1 & 1 & 1 & 5,69 \\
\hline 2 & 1 & 1 & 1 & 1 & 2 & 2 & 2 & 6,12 \\
\hline 3 & 1 & 1 & 1 & 1 & 3 & 3 & 3 & 7.80 \\
\hline 4 & 1 & 2 & 2 & 2 & 1 & 1 & 1 & 6,99 \\
\hline 5 & 1 & 2 & 2 & 2 & 2 & 2 & 2 & 7,09 \\
\hline 6 & 1 & 2 & 2 & 2 & 3 & 3 & 3 & 8,01 \\
\hline 7 & 1 & 3 & 3 & 3 & 1 & 1 & 1 & 6,89 \\
\hline 8 & 1 & 3 & 3 & 3 & 2 & 2 & 2 & 7,27 \\
\hline 9 & 1 & 3 & 3 & 3 & 3 & 3 & 3 & 7,65 \\
\hline 10 & 2 & 1 & 2 & 3 & 1 & 2 & 3 & 6,51 \\
\hline 11 & 2 & 1 & 2 & 3 & 2 & 3 & 1 & 7,04 \\
\hline 12 & 2 & 1 & 2 & 3 & 3 & 1 & 2 & 6,81 \\
\hline 13 & 2 & 2 & 3 & 1 & 1 & 2 & 3 & 7,09 \\
\hline 14 & 2 & 2 & 3 & 1 & 2 & 3 & 1 & 9,27 \\
\hline 15 & 2 & 2 & 3 & 1 & 3 & 1 & 2 & 9,78 \\
\hline 16 & 2 & 3 & 1 & 2 & 1 & 2 & 3 & 8,33 \\
\hline 17 & 2 & 3 & 1 & 2 & 2 & 3 & 1 & 6,79 \\
\hline 18 & 2 & 3 & 1 & 2 & 3 & 1 & 2 & 8,45 \\
\hline 19 & 3 & 1 & 3 & 2 & 1 & 3 & 2 & 8,03 \\
\hline 20 & 3 & 1 & 3 & 2 & 2 & 1 & 3 & 7,55 \\
\hline 21 & 3 & 1 & 3 & 2 & 3 & 2 & 1 & 6,78 \\
\hline 22 & 3 & 2 & 1 & 3 & 1 & 3 & 2 & 7,86 \\
\hline 23 & 3 & 2 & 1 & 3 & 2 & 1 & 3 & 7,00 \\
\hline 24 & 3 & 2 & 1 & 3 & 3 & 2 & 1 & 6,93 \\
\hline 25 & 3 & 3 & 2 & 1 & 1 & 3 & 2 & 8,08 \\
\hline 26 & 3 & 3 & 2 & 1 & 2 & 1 & 3 & 7,93 \\
\hline 27 & 3 & 3 & 2 & 1 & 3 & 2 & 1 & 7,92 \\
\hline & & & & & & & & \\
\hline
\end{tabular}

Perhitungan main effect dilakukan untuk mengetahui pengaruh dari masing-masing faktor dan interaksi terhadap hasil. Perhitungan main effect dilakukan dengan metode Signal to Noise Ratio (S/NR). Hasil perhitungan S/NR dengan menggunakan Minitab14:

Tabel 4. Hasil Perhitungan S/NR

\begin{tabular}{|c|c|c|c|c|c|c|c|}
\hline Level & $\mathrm{A}$ & $\mathrm{B}$ & $\mathrm{C}$ & $\mathrm{D}$ & $\mathrm{E}$ & $\mathrm{F}$ & $\mathrm{G}$ \\
\hline 1 & -16.92 & -16.76 & -17.10 & -17.66 & -17.18 & -17.36 & -17.01 \\
\hline 2 & -17.74 & -17.75 & -17.33 & -17.54 & -17.26 & -17.01 & -17.68 \\
\hline 3 & -17.56 & -17.71 & -17.79 & -17.02 & -17.78 & -17.85 & -17.53 \\
\hline
\end{tabular}

Rumus S/N Ratio untuk Smaller the better:

$$
\mathrm{S} / \mathrm{N}=-10 \log _{10}\left(\frac{\left(y_{1}^{2}+y_{2}^{2}+y_{3}^{2}+\cdots\right)}{n}\right)
$$

Dari Table 4 dapat dilihat bahwa faktor A level 1, faktor B level 1, faktor $\mathrm{C}$ level 1, faktor D level 3, faktor E level 1, faktor F level 2, dan faktor G level 1 
memberikan pengaruh paling kecil pada lemahnya ketahanan suatu aspal karena memiliki nilai S/NR paling besar. Ini berarti dengan komposisi agregat sebanyak 6.987,57 ton, dengan temperatur pelelehan aspal sebesar $155^{\circ} \mathrm{C}$, kecepatan pemadatan pengaspalan secepat $5 \mathrm{~km} / \mathrm{jam}$, waktu selama 4 jam sebelum proses pembukaan jalan untuk kecepatan normal, ketebalan aspal setebal $6,27 \mathrm{~cm}$, berat beban benda pengeras seberat 7 ton, dan dimensi (luas) sepanjang 5,598 $\mathrm{m}$ dapat menghasilkan komposisi aspal yang baik yang dapat mengurangi resiko lemahnya ketahanan aspal itu sendiri.

\section{Kesimpulan}

Berdasarkan dari nilai S/NR yang paling besar maka dapat disimpulkan bahwa komposisi optimal dari faktor-faktor yang memengaruhi ketahanan aspal adalah agregat (A) sebesar 6.987,57 ton, temperatur (B) sebesar $155^{\circ} \mathrm{C}$, kecepatan pemadatan (C) yaitu $5 \mathrm{~km} / \mathrm{jam}$, waktu pengerasan (D) selama 4 jam setelah pengaspalan sebelum proses pembukaan lalu lintas dengan kecepatan normal, ketebalan aspal (E) yaitu setebal $6,27 \mathrm{~cm}$ dari permukaan agregat, berat beban benda pengeras yaitu seberat 7 ton, dan faktor dimensi (luas) (G) yaitu seluas $5,598 \mathrm{~m}$.

\section{Daftar Pustaka}

[1] Bagchi, Tapan P. 1993, Taguchi Method Explained: Pratical Step to Robust Desaign, Prentice Hall, New Delhi.

[2] Ross, Phillip J, 1988, Taguchi Techniques for Quality Engineering, 2nd-ed

[3] Satuan Kerja Pelaksanaan Jalan Nasional Metropolitan Denpasar, 2012, Peningkatan Jalan Sp.Cokroaminoto-Sp. Tohpati (Jln. Gatsu Timur) 5,36 km, Denpasar, Bali.

[4] Sukirman, Silvia, 1999, Pekerasan Lentur Jalan Raya, NOVA, Bandung.

[5] Esme, Ugar, 2009, Application Of Taguchi Method for the Optimization of Resistance Spot Welding Process, Mersin University, Tarsus Technical Education, Faculty Department of Machine Education, Turki 